\title{
Philosophical notion of nature and the debate of Moral aspects of new technologie ${ }^{1}$
}

\author{
Zbigniew Liana \\ Pontifical University of John Paul II in Kraków
}

\section{Introduction: philosophy and the language for science- theology dialogue/debate.}

One of the most important roles philosophy plays in the dialogue between science, technology and theology is to provide an appropriate language. History shows that neither the language of theology nor the language of science can become a common ground for the interdisciplinary discussion. If one accept the thesis that linguistic meanings of particular languages of science and of theology are functions of specific methods of justification of these disciplines, it follows that the empiristic language (of science and technology) does not capture meanings of the religious language. Analogically, the religious language differs essentially, by definition, from the empiristic language, so it cannot be used as an adequate tool for interpreting empiristic meanings.

Nevertheless, a kind of exchange and communication between scientists (or philosophers) and theologians existed since ever. Even talking of contradictions and warfare presupposes a universal language for making comparisons. Without doubt, common language was used for these purposes. In common language, we can find both: interpretations of empirical theories and interpretations of religious beliefs.

However, common language being uncritical, it often led to misunderstandings and misconceptions. Very often one of the protagonists of the debate tended to predominate over the other. The important role of philosophy is to elaborate critically and to develop this comparative and interpretative role of common language.

\footnotetext{
${ }^{1}$ This is the English version of the Polish text: Z. Liana, "Filozoficzne pojęcie natury w kontekście sporów o moralny wymiar nowych technologii", in: M. Słomka (ed.), Nauka wiara. Rola filozofii, Wydawnictwo KUL, Lublin 2009, 45-57.
} 
If we agree with the thesis that the language of philosophy should be helpful in leading a critical dialogue, then the claim that this language should take into account contemporary language intuitions, widespread in contemporary science, religion and culture, seems well justified. Particular languages of science, technology and of theology and the universal language of philosophy, as well as common language, are mutually related and influencing each other. Common language and particular languages are the initial basis for critical, philosophical analysis of meanings. In its turn, philosophical language infiltrates backwards into common language, as well as into particular languages, leading to new modification of their linguistic meanings.

One of the most important philosophical, and consequently common, concepts shaping the debate between science, technology and theology was, through centuries since Middle Ages, the notion of nature. Originally a philosophical concept, it was used in order to reconcile rational and religious worldviews, taking consequently new specific connotations. This new concept of Nature underwent, since this time, an important evolution of meaning, losing in the common usage its original, medieval meaning.

It is my intention to present in this paper some tensions and problems arising in comparing original, medieval connotations of the notions of nature and law of nature with their modern understanding. These tensions have an important impact on the communicative value of the traditional expressions.

In particular my attention will focus on the concept of natural law, which is commonly used by some Christian theologians and philosophers in order to discuss ethical and normative aspects of new technologies. Contrary to this tradition, it seems that the above-mentioned evolution of meanings of the notions of nature and law of nature makes it difficult to treat them as an adequate instrument for contemporary ethical debate.

The critical part of the paper will be followed by an attempt to identify in modern culture new normative intuitions connected with the notion of nature. These intuitions are shaping the new language of nature that can be helpful for the ethical debate between theology, science and technology.

\section{Two metaphors of nature: contemplating and mastering Nature. ${ }^{2}$}

The new concept of Nature elaborated in the twelfth century in the School of Chartres was intended to reconcile the faith in the Creator with the existence of the apparently autonomic forces observed in the world.

\footnotetext{
${ }^{2}$ For a more detailed presentation of this problem see Z. Liana, Technology and the changing notion of nature, w: U. Görman, W. B. Drees, H. Meisinger (eds.), Creative Creatures. Values and Ethical Issues in Theology, Science and Technology, T\&T Clark: London-New York, 2005, ss. 34-44.
} 
The best expression of this concept we find in an evocative metaphor presented by a theologian Alan of Lille in his book De planctu naturae („On the plaint (or weeping) of Nature”).

Nature presents herself as beautiful Lady reminding a Greek goddess, wearing a mantle symbolizing the whole universe: heaven and earth together with all creatures living there. The author, being a Christian, calls her child of God (Dei proles). However, in the same time he calls her with very significant names of the Mother of things (genitrix rerum) and God's assistant (vicaria Dei). She helps God in governing and ruling the created world. Her duty is to introduce harmony and order into the primordial chaos of matter created ex nibilo by God himself. This truth is expressed with many various words: stable nexus, bondage of the world, biding agent of the world, peace, love, order, law, term, way, source, light, rule of the world etc. ${ }^{3}$ The ultimate source of this ordering and normative role of Nature is God's Logos: an eternal and complicated in absolute simplicity archetype (forma) of Nature and of the Universe.

According to this metaphor, Nature is a norm of behavior for the whole world, including man. However, because of the wrong use of the free will man becomes rebellious against Nature and causes her plaint and weeping. All other creatures pay obediently due tribute to her.

This metaphor presupposes and in the same time suggests that man can only be an observer of nature. It lacks any space for an active cooperation of man with nature, and even less for changing it. No wonder, if we take into account the level of development of technology in these times. The Christian thinkers did not feel constraint to take any position on this problem. Contemplation and obedience of Nature are the key words describing the right relationship between man and Nature - obedience to the Nature means obedience to God himself.

The notion of an active intervening into Nature appears only during the Renaissance, on the ground of the quite commonly accepted alchemical and magical paradigm of interpreting Nature. In the new metaphor, Nature is not anymore a perfection and goal of all creatures but itself undergoes a process of evolution and improvement. ${ }^{4}$ The idea of an unchangeable nature being the normative law of a thing is replaced by the

\footnotetext{
${ }^{3}$ See Magistri Alani enchiridion de planctu nature, N. M. Häring (ed.), „Studi Medievali” 19 (1978), fasc. 2, 831n. See also Z. Liana, Koncepcja Logosu i Natury w Szkole w Chartres [The Notions of Logos and Nature in the School of Chartres], OBI PAT-BRE: Kraków 1996, 217-232.

${ }^{4}$ See Z. Liana, Okultyzm a nauka $w$ okresie przedoświeceniowym [Science and the Occult in the Pre-Enlightenment Period], in: M. Heller, Z. Liana, J. Mączka, W Skoczny, Nauki przyrodnicze a teologia: konflikt $i$ wspótistnienielScience and Theology: Conflict and Coexistencel, OBI-Biblos: Kraków-Tarnów 2001, 169-298; esp. 249-262. I am writing there also about few examples of critical attitude against magic and alchemy in this period, and about limited impact of these critics: 271-287.
} 
idea of an absolute "lawlessness" of Nature. There is only one law or rule governing the behavior of Nature: "Nature can everything".

Nevertheless this metaphor is also deeply rooted in Christian thought. After the Fall of man the whole Nature became corrupted and needs redemption. Magus is a man who cooperate with God in redeeming Nature, leading it to its perfection (f. ex. philosophers' stone). Many thinkers are drawing analogies between Jesus Christ and philosophers' stone. Some, like Luther, are praising alchemy for excellent theological allegories.

The idea of a magus and alchemist who transmute and perfects Nature became, without doubt, an archetype of the later image of scientist and technician, who not only contemplates nature like a medieval man, but also makes efforts to unveil hidden mysteries of Nature in order to change and improve it for the needs of man. Descartes bears us an important witness to this idea, when he writes in his Discourse on Method that man became „as it were master and possessor of nature”. The old image of contemplation and obedience changes into the new image of mastering and improving nature. In this context, nature loses its normative aspect.

\section{Normativity of nature in the contemporary culture.}

Today's technology and science fits much better to this second, going back to the Renaissance, metaphor of mastering nature and improving it. We can easily find some extreme interpretations of this metaphor in modern culture. For example some authors, when talking of biotechnology, say that man is "playing God”. In the Christian theology new term of „created cocreator" was coined. ${ }^{7}$ This last metaphor acknowledges the created status of man, but in the same time it lays stress on his calling for an active cooperation with God in the work of creating Nature. In some sense, man takes position that in the medieval metaphor was proper to the Nature herself. On one side, Nature creates man, on the other, man, together with God, creates Nature. Actual Nature, as it exists, is incomplete and imperfect.

Therefore, in the context of modern science and technological capabilities fundamental question arises: if, and how, can we talk today about the normative character of nature for human activity in science and technology? Did the metaphor of mastering and improving nature completely supersede the metaphor of contemplation and obedience, or may be the replacement is only a kind of an unwarranted absolutization of this metaphor?

\footnotetext{
${ }^{5}$ On this expression, see A. Koyré, Mystiques, spirituels, alchimists du XVIe sičcle allemand, Gallimard: 1971, 83...

6 Discourse on Method: and Meditations on First Philosophy, transl. D. A. Cress, Indianapolis: Hackett Publishing Co. 1993, $3^{\text {rd }}$ edn, 35.

${ }^{7}$ See for example papers included in: U. Görman, W. B. Drees, H. Meisinger (eds.), Creative Creatures. Values and Ethical Issues in Theology, Science and Technology, T\&T Clark: London-New York, 2005.
} 
In this context, we have to ask whether the idea of natural law, widely accepted by Christian (mainly Roman Catholic) theologians and moral philosophers, can be an answer to these questions. And whether common acceptance of the seemingly analogical term "law of nature” in the field of science is not a sufficient warrant for using the notion of natural law in the field of morals? Both notions seem to evoke normative aspects of nature.

Without entering historical details, one can say that the metaphor of Alan of Lille became an archetype for the later concept of law of nature. This concept, similarly to the notion of nature, was related to the events happening in the material world as well as to the free actions of man. With time, the distinction was made between the concept of moral, natural law respecting free human will, and the concept of deterministic law of nature. This linguistic fact made it easier for Christian theologians and for Churches the acceptance of the idea of deterministic laws of nature.

Both concepts originally had normative meaning. With time, however, scientific practice led gradually to the new methodological interpretation of law of nature. First, the distinction was made between the purely metaphysical unchangeable laws of nature and hypothetical, temporary laws of science. One of the proponents of this distinction was in 1830 John Herschel. In his Preliminary Discourse on the Study of Natural Philosophy, he distinguishes between the laws of nature, imposed by God, and the laws of nature understood as words formulas of scientists. ${ }^{8}$ Words formulas are only attempting, in an imperfect way, to reach reality itself. The normativity of laws of nature becomes relegated to the unknowable empirically and very often questioned domain of metaphysics. The laws discovered by scientists turned out to be vulnerable in the contact with empirical facts and depending heavily on subjective epistemic constraints. Later, many scientists will eliminate from their vocabulary the metaphysical notion of "law of nature" at all, identifying it simply with hypothetical and temporary "scientific law".

With this change in meaning, the concept of law of nature loses its original normative character related to the normativity of the nature herself. The normativity of scientific laws is purely nominal, related with their logical form. The problem of a real correspondence of normative scientific laws - whether any normative aspect in reality itself corresponds to the normativity of scientific laws - is a philosophical problem (metaphysical and epistemological), related to the widely debated today problem of theoretical realism. Contemporary philosophy very rarely answers the question concerning real reference of scientific laws using the notion of law of

\footnotetext{
${ }^{8}$ See sections 27 and 89.
} 
nature. Rather, philosophers prefer to speak of regularities, structures and qualities of nature, imperfectly known through scientific laws of nature.?

The fact that the notion of laws of nature lost its original normative and strongly realistic character is not a sufficient argument for denying these characteristics to the notion of moral natural law. However, one cannot not to see the real consequences of this fact for the ethical debate between science, technology and theology. In today's culture, those two notions of natural law and of law of nature have nothing in common but medieval roots. They differ in their normative aspects. They differ also in epistemologies, in which they are rooted. These differences very easily lead to misinterpretations and misunderstandings, if one of the parties of the debate forget that the similitude of terms does not imply the similitude of meanings. These concepts instead of being analogical are rather equivocal.

The notion of natural law requires a specific epistemology. In order to speak of natural law as of something known with certainty and truth, it is necessary to accept beforehand the possibility of knowing the metaphysical reality and the existence of a corresponding method of justification of this knowledge. Independently of the position we take in this respect, it is a fact, that philosophers are seriously quarreling about it since several centuries, and the compromise seems to be rather unattainable.

In this contexts the following thesis seems to be justified: Even if man does have intuitions concerning what is right and what is wrong, what is permitted and what is forbidden (i.e. the traditional natural law), he does not have any infallible method of intersubjective justification of the knowledge of this kind. In this new epistemological perspective, the knowledge of natural law can only be hypothetical, similarly to the knowledge of the regularities of nature. The notion of natural law can only be an ideal category to the knowledge of which we are tending, without ever having intersubjective guarantees of reaching it.

Guarantees can be take form the Revelation, but in this case the notion of natural law becomes a theological category and stops to be a philosophical one. The problem with this kind of categories is that they are convincing only those who were convinced beforehand. They are useful for internal apologetic purposes rather than for a dialogue with the so-called "world".

Our consent for eliminating the language of natural law as an appropriate linguistic framework for the science, technology and theology dialogue does not imply necessarily, however, the conclusion that the notion of normativity became useless in our talking about nature. Simple analysis, historical and conceptual, shows quite the contrary. Both metaphors, of

\footnotetext{
9 This was for example the position of K. R. Popper. Today it is taken by M. Heller, N. Cartwright and others.
} 
contemplation and of mastering, do not exclude themselves, but should be treated as complementary, and their one-sided absolutization should be regarded as a kind of a philosophical reductionism.

It is not difficult to show that the idea of mastering and changing nature is present in human culture since its very beginning. The evident differences between epochs relate only to the range of human capacities to perform these changes. With time, this range becomes significantly larger and larger. New areas of phenomena result 'accidental', susceptible of human intervening and change.

On the other side, it is also quite easy to show that man can never be an absolute master of nature. He has always to respect some rules, not depending on him. This aspect of contemplation and obedience can be traced also in modern science and technology. One of the most fundamental experiences of many scientists and technicians ('engineers') is the resistance of the so-called reality. Reality is a severe judge of human theoretical inventions. It imposes some unavoidable limits. Researching nature requires a humble attitude.

The same humility is required in the field of technology. Mastering nature can be performed only within a framework of known rules imposed by reality itself (nature). Technology cannot be a creatio ex nibilo - neither of matter nor, a fortiori, of regularities and qualities discovered in nature. This is also true even for very controversial aspects of genetic engineering. The only things that can be 'created' by man are new forms or structures, which without human intervention would remain pure hidden possibilities.

\section{New 'ecological' understanding of nature}

However, the normative character of nature in contemporary culture should not be looked for in the limitations imposed on science and technology by reality itself. Rather, it should be searched in common experience of some values surfacing in the context of human relationship with nature. These values are surfacing especially there, where the uncontrolled development of technology begins to jeopardize man him/herself (as an individuum and as a species). In this context, nature starts to exhibit its value that should be protected. Environmentalist movements are only an expression of the awareness of this value in modern society.

Not every change in nature, not every human intervening in nature proves itself, with time, beneficial for man. Original, uncritical enchantment with industry, with chemical products etc. quickly turned out to be too far optimistic. Intended as a remedy for famine, poverty and malady new technologies led also to the severe deterioration of human environment, menacing man to the same extent as 'natural' dangers. The abuse of new technologies infringed a very frail equilibrium of nature. Because of 
this, an important part of today's scientific and technological efforts must be directed to remedy the effects of the previous abuse.

We discover the same hopes and fears when talking about development of genetic engineering. Nobody can predict all far-reaching effects of contemporary research in this field for natural and human environment. This uncertainty gives rise to justified concerns and calls for prudence. Nevertheless, the fear of the unknown cannot paralyze human activity. The call for cooperation with God in changing nature is also an essential part of human religious and self-understanding. Hence, what is needed is continuous working out of prudent answers and decisions, reconciling both, the will of 'creating' new things and the justified fear of total destabilization of natural and human equilibrium.

As an example of this necessity for a prudent compromise can be given the problem of genetically modified food. On one side, there are fears of wealthy societies concerning healthy food. On the other, there are calls of poor countries, damaged by natural cataclysms, like drought, for new transgenic crops that could be easily cultivated in the difficult climate.

Through the experience of ecological threat appears a completely new aspect of Nature. It is not anymore powerful in governing and ruling universe. It is vulnerable and susceptible of destruction. Nature cannot be reduced to the universe describable with most general theoretical laws. Nature is also, or may be mainly, an environment for human being and man itself. This new aspect of Nature turns out to be a frail and subtle equilibrium of many factors. The full knowledge of the net of mutual dependencies, creating this equilibrium, probably will remain always impossible.

This ecological experience is followed by an another experience, which shows that human environment does not limit itself to what is external to man. Man him/herself is a kind of a frail equilibrium, together with his/her biological, psychological and social dependencies. Moreover, this experience shows that the ecological 'nature' of man includes also 'transcendent' values of human person and its dignity. Protecting those values is equally necessary for preservation of human equilibrium. For example, when talking of some serious educational problems with teenagers in schools in many developed countries, escalating in last period, one can say that a certain subtle human equilibrium - difficult even to define was destroyed, leading to unpredictable, to some extent, effects.

The new ecological language of nature, of nature understood as an ecological equilibrium, and the language of values related to this equilibrium can be really helpful in proposing a new framework for the debate between science, technology and theology concerning moral and normative aspects of new technologies. This new language seems to be well understandable and acceptable for all parties of the debate. Of course, this new language does not give the same possibilities as the language of natu- 
ral law. Within this language, it is difficult to speak of definitive solutions or of an absolute knowledge of norms and values of nature. Nature as an equilibrium and subtle harmony is a deep mystery, unveiled painfully, with errors often difficult to predict a priori.

\section{Conclusions}

1/ The protagonists of the science, technology and theology dialogue should avoid absolutizing of any of the metaphors of nature. Theology should not limit its notion of moral and normative aspects of nature to the aspect of contemplation and obedience of man to nature. Human beings are called not only to respect nature but also to improve it for the good of men. On the other side, science and technology should assess critically and cautiously all possibilities opened to them by the progress. The awareness of the frail equilibrium of nature, that can easily be destroyed, can be helpful for this purpose.

2/ The knowledge of natural and normative good of man - putting aside the Christian Revelation - must not necessarily be certain and ultimate. Modern epistemology argues rather to the contrary: our philosophical and empirical knowledge of the 'nature' of man never is perfect and universal, analogically to the knowledge of the empirical world. Our natural intuitions and beliefs concerning natural good of man may not be true and universally intersubjective (valid, shared), even if accompanied with subjective (and collective) evidence. In this context, the identification of the so-called natural laws should be approached with due caution.

3/ It could be helpful for the dialogue to replace the traditional language of natural law with the new language of ecological value of nature, because contemporary experience of value and normativity of nature is related to the former. The language of natural law seems to be detached from the experience that originally shaped its normative and realistic meaning. In the context of modern epistemologies, this language is perceived as a particular language of theology rather than as a universal language of philosophy and common language.

4/ As far as absolute values and norms, revealed by God, are concerned, Christians have to bear witness to them and to give rational arguments in favor of them, without however expecting that these arguments will become apodictic demonstrations of values and norms.

\section{References}

ALAN OF LILLE: Magistri Alani enchiridion de planctu nature, N. M. Häring (ed.), „Studi Medievali” 19 (1978), fasc. 2, 831n. 
DESCARTES: Discourse on Method: and Meditations on First Philosophy, transl. D. A. Cress, Indianapolis: Hackett Publishing Co. 1993, $3^{\text {rd }}$ edn.

GÖRMAN, U. - DREES, W.B. - MEISINGER, H. (eds.): Creative Creatures. Values and Ethical Issues in Theology, Science and Technology, T\&T Clark: London-New York, 2005.

HERSCHEL, J.: Preliminary Discourse on the Study of Natural Philosophy

KOYRÉ, A.: Mystiques, spirituels, alchimistes du XVIe sičcle allemand, Gallimard, 1971.

LIANA, Z.: Okultyzm a nauka w okresie przedoświeceniowym [Science and the Occult in the Pre-Enlightenment Period], in: M. Heller, Z. Liana, J. Mączka, W Skoczny, Nauki przyrodnicze a teologia: konflikt $i$ wspótistnienie [Science and Theology: Conflict and Coexistence], OBI-Biblos: Kraków-Tarnów 2001, 169-298.

LIANA, Z.: Koncepcja Logosu $i$ Natury $w$ Szkole $w$ Chartres [The Notions of Logos and Nature in the School of Chartres], OBI PAT-BRE: Kraków 1996, 217-232

LIANA, Z.: Technology and the changing notion of nature, in: U. Görman, W. B. Drees, H. Meisinger (eds.), Creative Creatures. Values and Ethical Issues in Theology, Science and Technology, T\&T Clark: LondonNew York, 2005, 34-44. 